\title{
ПЕРСПЕКТИВА ВИКОРИСТАННЯ СЛИЗУ РІЗНИХ ВИДІВ РАВЛИКІВ У МЕДИЦИНІ
}

\author{
Перспектива використання слизу різних видів \\ равликів у медицині \\ Т. А. Грошовий, Б. В. Павлюк, М. Б. Чубка, \\ М. М. Добринчук \\ Тернопільський національний медичний університет \\ імені І.Я. Горбачевського мОЗ України
}

Резюме. Здавна відомо про терапевтичні властивості слизу різних видів равликів. У світі зростає інтерес науковців щодо можливостей застосування слизу равликів різних видів, зокрема Helix pomatia, Helix aspersa maxima, Helix aspersa muller у медицині.

Мета дослідження - узагальнити дані літературних джерел щодо перспективності використання слизу равликів як активного фрармацевтичного інгредієнта у медичній галузі та у фармацевтичній промисловості.

Матеріали і методи. Проаналізовано та узагальнено дані понад 50 джерел, із яких у даному огляді використано 30 джерел сучасної іноземної та вітчизняної літератури щодо доцільності використання слизу равликів у медицині, фрармації та косметології. У дослідженні опрацьовано наукові публікації за останнє десятиліття, які доступні у мережі «lнтернет», ключовими словами були муцин, слиз, равлик, ліофілізація, технологія ліків.

Результати. На основі представлених літературних даних можна зробити висновок, що слиз равлика має велике практичне значення для різних галузей медицини (дерматологія, ортопедія, терапія), широко використовується у технології лікарських засобів як активний фрармацевтичний інгредієнт та основа для трансдермальних терапевтичних систем. Фармакологічна активність слизу равликів забезпечується збагаченим хімічним складом, адже активними компонентами є протеоглікани, глікозаміноглікани (зокрема, гіалуронова кислота), глікопротеїнові фрерменти, амінокислоти, пептиди (мідні, антимікробні), вітаміни (A, C, E, $B_{1}$ та $\left.B_{6}\right)$, макро- та мікроелементи ( $\mathrm{Na}, \mathrm{Ca}, \mathrm{K}, \mathrm{Mg}, \mathrm{P}, \mathrm{Cu}, \mathrm{Zn}, \mathrm{Fe}, \mathrm{Mn})$, муцин, колаген, гліколева кислота, еластин та алантоїн. Доведено, що слиз равликів має антиоксидантні, антибактеріальні, регенеративні, протизапальні властивості, а також при його застосуванні забезпечується зволожувальна, очищувальна та захисна дії.

Висновки. На сьогодні слиз равликів широко використовують у дерматології та косметології, що підтверджують результати фрармакологічних досліджень. Актуальним та перспективним є використання слизу як основи-носія для створення лікарських
The prospect of using the mucus of different species of snails in medicine

T. A. Hroshovyi, B. V. Pavliuk, M. B. Chubka, M. M. Dobrynchuk

I. Horbachevsky Ternopil National Medical University e-mail: vons@tdmu.edu.ua

Summary. It has long been known about the therapeutic properties of the mucus of different species of snails. There is a growing interest in the world in the possibilities of using the mucus of snails of various species, in particular, Helix pomatia, Helix aspersa maxima and Helix aspersa muller in medicine.

The aim of the study - to summarize the data of literature sources on the prospects of using snail mucus as an active pharmaceutical ingredient in the medical field and in the pharmaceutical industry.

Materials and Methods. Data frommore than 50 sources were analyzed and summarized, of which 30 sources of modern foreign and domestic literature on the feasibility of using snail mucus in medicine, pharmacy and cosmetology were used in this review. The study examined scientific publications over the past decade, which are available on the Internet; the key words were mucin, mucus, snail, lyophilization, drug technology.

Results. Based on the presented literature data, it can be concluded that snail mucus is of great practical importance for various fields of medicine (dermatology, orthopedics, therapy), is widely used in drug technology as an active pharmaceutical ingredient and basis for transdermal therapeutic systems. The pharmacological activity of snail mucus is provided by an enriched chemical composition, as the active components are proteoglycans, glycosaminoglycan (in particular, hyaluronic acid), glycoprotein enzymes, amino acids, peptides (copper, antimicrobial), vitamins (A, C, C, E, B) and trace elements ( $\mathrm{Na}, \mathrm{Ca}, \mathrm{K}, \mathrm{Mg}, \mathrm{P}, \mathrm{Cu}, \mathrm{Zn}, \mathrm{Fe}, \mathrm{Mn}$ ), mucin, collagen, glycolic acid, elastin and allantoin. It is proved that snail mucus has antioxidant, antibacterial, regenerative, anti-inflammatory properties, as well as its use provides moisturizing, cleansing and protective effects.

Conclusions. Today, snail mucus is widely used in dermatology and cosmetology, which confirms the results of pharmacological studies. The use of mucus as a carrier base for the development of drugs, as well as an active pharmaceutical ingredient with a 
засобів, а також як активного фрармацевтичного інгредієнта з широким спектром фрармакологічної дії.

Ключові слова: муцин; слиз; равлик; ліофрілізація; технологія ліків.

\section{ВСТУП}

Дані про терапевтичні властивості слизу різних видів равликів відомі вже багато років, ще в Стародавній Греції його використовували з лікувальною метою при захворюваннях шлунково-кишкового тракту (пептичні виразки, гастрити), для загоєння опіків та ран різного походження як знеболювальний засіб, а також на його основі виготовляли муколітичні та відхаркувальні сиропи $[1,2]$.

На сьогодні у світі зростає інтерес науковців щодо можливостей медичного застосування слизу равликів різних видів, зокрема Helix pomatia, Helix aspersa maxima, Helix aspersa muller [3]. А томy вчені вже упродовж багатьох років намагаються вивчити складові компоненти слизу, проаналізувати хімічний склад, ідентифрікувати та визначити вміст біологічно активних речовин з метою обґрунтування прояву певних видів активностей слизу різних видів равликів [4]

Управління 3 санітарного нагляду за якістю харчових продуктів та медикаментів США (Food and Drug Administration (FDA)) також зацікавилося лікарськими засобами, розробленими на основі слизу та інших продуктів життєдіяльності равликів. Так, препарат «Prialt ${ }^{\circledR}$ », активним фрармацевтичним інгредієнтом якого $є$ зіконотид, перебуває під наглядом FDA ще з 1999 р. та схвалений для лікування хронічного болю [5].

Слиз равликів як у нативному, так і в ліофілізованому вигляді викликає велику зацікавленість у фрахівців фрармацевтичної та косметичної галузей, особливо з погляду технології косметичних засобів, а також технології різних фрорм лікарських засобів, призначених для профрілактики та лікування певних захворювань [4].

Метою дослідження було узагальнити дані літературних джерел щодо перспективності використання ліофілізованого слизу равлика у медичній галузі та у фрармацевтичній промисловості.

\section{МАТЕРІАЛИ I МЕТОДИ}

Ми проаналізували та узагальнили дані понад 30 джерел сучасної іноземної та вітчизняної літератури щодо доцільності використання слизу равликів у медицині, фрармації та косметології.

\section{РЕЗУЛЬТАТИ Й ОБГОВОРЕННЯ}

Секрет, що продукується спеціальними епідермальними слинними залозами, які розташовані на нозі молюска, називається слизом. Загалом, рав- wide range of pharmacological action is relevant and promising.

Key word: mucin; mucus; snail; lyophilization; drug technology.

лики виробляють щонайменше 2 типи слизу: один - менш в'язкий, з високим вмістом води (96-97 \%), другий - більш в'язкий та липкий [6]. Слиз є рідкою, гігроскопічною, в'язкоподібною речовиною кислого характеру (рН дорівнює 3), що покриває всю зовнішню поверхню равлика [7, 8]. Він характеризується неньютонівськими властивостями, має вигляд твердого клею у стані спокою, та розріджується при прикладанні відповідного напруження зсуву [7].

Хімічний склад слизу равликів характеризується наявністю протеогліканів, глікозаміногліканів (зокрема несульфратованого глікозаміноглікану гіалуронової кислоти), глікопротеїнових фрерментів, амінокислот, пептидів (мідні, антимікробні), вітамінів (A, C, E, B 1 та B $)$, макро- та мікроелементів ( $\mathrm{Na}, \mathrm{Ca}, \mathrm{K}, \mathrm{Mg}, \mathrm{P}, \mathrm{Cu}, \mathrm{Zn}, \mathrm{Fe}, \mathrm{Mn}$ ). У слизі ідентифріковано муцин, колаген, гліколеву кислоту, еластин та алантоїн [7]. Методом атомно-абсорбційної спектрометрії визначено, що слиз Arion subfuscus містить значні кількості цинку, заліза, міді та марганцю [9].

Різноманітний хімічний склад та наявність представників різних груп біологічно активних речовини забезпечують антиоксидантні, антибактеріальні, регенеративні, протизапальні властивості, а також забезпечують зволожувальну, очищувальну, захисну дії слизу равликів [7].

Наявність у слизі пептиду муцину, який проявляє антибактеріальну активність щодо грампозитивних та грамнегативних мікроорганізмів, дає можливість охарактеризувати дію його як природного антибіотика, окрім того, доведено, що антимікробні пептиди проявляють імуностимулювальну активність [10].

Результати досліджень підтверджують, що алантоїн у складі слизу забезпечує регенеративну та ранозагоювальну дію, проявляє пом'якшувальну, захисну дію на шкіру, зменшує подразнення. У складі слизу містяться білки, колаген та еластин, які відповідають за пружність і гладкість епідермісу, окрім цього, колаген і еластин $€$ необхідними протеїнами для формування сполучної тканини. Завдяки наявності у складі пептидів (зокрема природних антибіотиків) та вітамінів знищується патогенна мікрофрлора та фрормується бар'єрний шар епідермісу. 3-поміж виявлених найкориснішими для шкіри вітамінами є ретинол, токоферол та кислота аскорбінова [11]. Наявна у слизі гліколева кислота сприяє видаленню ороговілих частинок 3 верхнього епідермального шару, вирівнюванню ко- 
льору шкіри та її поверхні; допомагає нормалізувати природнє відновлення та активізувати власні резерви шкіри, стимулювати вироблення протеїнів, які сприяють пружності та зволоженості шкіри. Цінним компонентом слизу равликів $€$ наявність арахан сульфату - природної речовини, яка за дією прирівнюється до гіалуронової кислоти. Арахан сульфат підвищує еластичність шкіри, запобігає передчасному її старінню [12].

Наприкінці двадцятого століття (а точніше, 3 1995 р.) у косметології активно почав розвиватися напрямок з використання слизу різних видів равликів. На сьогодні, завдяки збагаченому складу, слиз равликів (у вигляді концентрованого екстракту або ліофілізованого порошку) широко використовують провідні світові виробники косметичних засобів, на його основі випускають багато кремів, гелів, мазей та інших засобів з догляду за шкірою обличчя. Зазвичай, слиз равлика $є$ активним компонентом косметичних засобів (найчастіше - кремів) натурального походження із зволожуючою дією, характерною особливістю яких є гіпоалергенність [13].

У технології лікарських чи косметичних засобів слиз равлика найкраще використовувати як концентрований та максимально очищений компонент. Тому оптимальним є використання ліофілізованого порошку із слизу, який має вигляд сухої порошкової маси із характерним природним запахом. Для цього слиз равлика необхідно попередньо заморозити у розчині рідкого азоту та висушити при температурі від $-40{ }^{\circ} \mathrm{C}$ до $+35^{\circ} \mathrm{C}$ впродовж 20-24 год, що дозволяє зберегти активні компоненти слизу в незмінному стані та забезпечити стабільність ліофілізату протягом певного періоду.

Також слиз равликів широко використовують у складі лікарських засобів для профрілактики та/ або лікування дерматологічних захворювань. Так, в Італії та Кореї для лікування дерматитів, акне, мозолів і вугрів, та для покращення загоєння ран застосовують препарати, активним компонентом яких також є слиз равликів [14]. Автори [14] довели, що поєднання хітозану та 1,5 \% слизу равлика пришвидують процес загоєння ран, при цьому оптимальним співвідношенням 100 \% слизу та 1,5 \% суміші хітозану є 1:2.

У США розроблено патент (US2009026349), який описує можливе використання слизу як носія для терапевтичних систем, що призначені для лікування опіків та дерматологічних захворювань, а також як захисне покриття при лікуванні цих та інших ран [15].

Наукові підтвердження можливого використання слизу равликів при лікуванні ран можна знайти у праці, опублікованій у 2008 р. [16]. Автори визначили, що слиз Cryptomphalus aspersa (також відомий як Helix aspersa або звичайний садовий равлик) містить антиоксидантну супероксиддис- мутазу та глутатіон-S-трансфреразу, які фрормують ферментну ланку антиоксидантної системи захисту [16]. Захист клітинних структур від активних форм кисню відбувається різними шляхами залежно від їх походження (екзогенного та ендогенного) та здатності проникати через біологічні мембрани. Супероксиддисмутаза бере активну участь у захисті клітинних структур від активних фрорм кисню шляхом їх елімінації. Глутатіон-S-трансорераза належить підсистеми глутатіонтрансорераз глутатіонової системи антиоксидантного захисту, яка є найважливішим компонентом системи детоксикації токсичних метаболітів та ксенобіотиків [17]. Автори [16] також підтверджують, що слиз равликів стимулює проліферацію фрібробластів та має вплив на регулювання активності металопротеїназ, що разом забезпечують ряд молекулярних механізмів, які лежать в основі клітинної регенерації, тим самим обґрунтовуючи можливе застосування при ушкодженні тканин.

Експериментально визначено, що при місцевому застосуванні порошкоподібного слизу сухопутного равлика (Megalobulimus lopesi) на експериментальній рановій поверхні у щурів лінії Wistar спостерігається ранозагоювальний ефект. 3 цією метою тварин розподіляли на три групи: G1 - контрольна без застосування терапії; G2 - застосування крему, який використовували один раз в день; G3 - використання порошкоподібного матеріалу шляхом змішування його з готовим кремом у співвідношенні 1:1. Результати дослідження показали, що площі ранових поверхонь у досліджених тварин на 3; 7 та 14 доби були меншими у випадку застосування порошкоподібного матеріалу, порівняно 3 контрольною групою та групою, для якої використовували препарат-порівняння, окрім того, рани повністю затягнулися на 21 добу експерименту. В ході дослідження спостерігалося збільшення кількості судин у ділянці рани, підвищення кількості лейкоцитів у периферичній крові, посилення ранньої запальної реакції (локально та системно) без подальшого ушкодження тканин. Результати свідчать, що застосування м'якої фрорми з досліджуваного засобу сприяє прискоренню процесу загоєння ранової поверхні, хронізація якого збільшує ризики зараження рани умовно-патогенними мікроорганізмами [18].

Як відомо, однією з головних проблем охорони здоров'я $€$ антибіотикорезистетність мікроорганізмів. Упродовж останніх років було проведено багато досліджень щодо визначення антимікробної активності слизу різних видів равликів, особливо щодо мікроорганізмів, стійких до багатьох лікарських засобів, наприклад метицилінрезистентного золотистого стафрілокока. Результати проведених досліджень вказують на доцільність та перспективність подальшого вивчення антимікробних 
властивостей слизу равликів, активні компоненти (природні пептиди) якого можуть стати основою препаратів потенційної альтернативної терапії звичайним антибіотикам [19].

Визначено, що слиз равлика Achatina fulica містить антимікробний пептид mytimacin-AF, який складається 380 амінокислотних залишків, включаючи 10 залишків цистеїну. Mytimacin-AF виявляє потужну антимікробну активність щодо грамнегативних та грампозитивних мікроорганізмів та грибка Candida albicans. Серед вивчених мікроорганізмів найсильнішу антимікробну активність даний пептид (мінімальна концентрація пептиду - 1,9 мкг/мл) проявив щодо золотистого стафілокока $[20,21]$.

Відомо також про перспективу використання слизу равликів в ортопедії. Науковці [22] встановили, що слиз гігантських африканських сухопутних равликів містить кристали кальциту, а тому слиз може мати практичне застосування в ортопедії як біологічно сумісний матеріал («кістковий цемент») природного походження, що сприяє механізмам загоєння та зміцнення кісток [22].

Встановлено, що в слизі равлика Helix pomatia міститься мукоглікопротеїн геліцидин, який характеризується добре вираженою протикашльовою активністю [22]. Результати досліджень підтвердили, що геліцидин сприяє зменшенню кількості та тривалості нападів кашлю у період сну, а тому може бути рекомендований як протикашльовий засіб для лікування непродуктивного кашлю, особливо для пацієнтів, яким опіоїдні чи антигістамінні протикашлеві засоби протипоказані [24].

Надзвичайно актуальними на сьогодні $є$ дані щодо протиракової активності слизу певних видів равликів. Так, група науковців визначила, що екстракти з тканин Helix aspersa мüller володіють протираковою активністю щодо клітин раку молочної залози (Hs578T) [25]. Доведено, що дві фрракції слизу гігантського африканського равлика (Achatina fulica) знижують життєздатність клітин раку молочної залози (МСF-7) [26]. Активні компоненти (гемоціаніни, кисневі металопротеїни гемолімфри та їх ізоформи) слизу сухопутного равлика (Helix lucorum) та морського равлика

\section{СПИСОК ЛІТЕРАТУРИ}

1. HelixComplex snail mucus exhibits pro-survival, proliferaive and pro-migration effects on mammalian fibroblasts / C. Trapella, R. Rizzo, S. Gallo [et al.] // Scientific Reports. - 2018. - Vol. 8 (17665). - P. 1-10. DOI:10.1038/ s41598-018-35816-3.

2. Bonnemain B. Helix and drugs: snails for health care from Antiquity to these days / B. Bonnemain // Rev. Hist. Pharm. - 2003. - Vol. 51 (338). - P. 211-218.

3. Bouchet P. Classification and nomenclator of gastropod families / P. Bouchet, J. P. Rocroi // Malacologia:
(Rapana venosa) проявляють протиракові ефекти на клітини раку сечового міхура людини [27]. Відомо, що гемоціаніни, виділені з Helix aspersa müller, знижують життєздатність клітин раку яєчників (FraWü), клітин раку передміхурової залози (DU-145), гострих клітин моноцитарного лейкемії (THP-1) [28].

Необхідно акцентувати увагу також на білкових компонентах отрути конусоподібних равликів, яких на сьогодні налічується понад 750 видів. Отрута таких равликів містить безліч пептидів (конотоксинів), які містять від 10 до 40 амінокислот. Конотоксини використовують як фрармакологічні засоби для вивчення больової сигналізації, оскільки їх дія та селективність дозволяють вивчити окремі підтипи іонних каналів, що раніше було неможливо, а тому можуть в перспективі фрормувати новий клас анальгетиків. На сьогодні виявлено понад 10000 послідовностей конотоксину [29].

Синтетичною фрормою пептиду $\omega$-конотоксину, який одержують із отрути конусоподібного равлика Conus magus $€$ зіконотид [30], який є селективним блокатором кальцієвих каналів нейронного типу. Зіконотид використовується як нетиповий знеболювальний засіб при сильному та хронічному болю, при цьому за дією він є потужнішим у 1000 разів від дії морфріну гідрохлориду [31]

У цілому, слиз равликів $є$ природним гіпоалергенним продуктом, тому не викликає алергічних реакцій. Проте як і будь-який навіть самий безпечний засіб, в деяких випадках варто використовувати з обережністю.

\section{ВИСНОВКИ}

Результати короткого огляду літератури підтверджують перспективність використання слизу равликів у медицині та фрармації. На даний час найбільш широко використовується слиз равликів у дерматології та косметології, що підтверджують результати фрармакологічних досліджень.

Актуальним та доцільним $€$ використання слизу як основи-носія для створення лікарських засобів, а також як активного фрармацевтичного інгредієнта, який проявляє широкий спектр фармакологічної дії (антиоксидантна, протизапальна, регенеруюча та ін.).

International Journal of Malacology. - 2005. -Vol. 47 (1-2). - P. 397.

4. Bonnemain B. Helix and drugs: snails for western health care from antiquity to these present / B. Bonnemain // Evid Based Complement Alternat Med. - 2005. - Vol. 2, Is. 1. - P. 25-28. DOI: 10.1093/ecam/neh057.

5. Conotoxins: Chemistry and Biology / A.-H. Jin, M. Muttenthaler, S. Dutertre [et al.] // Chemical Reviews. 2019. - Vol. 119 (21). - P. 11510-11549. DOI: 10.1021/acs. chemrev.9b00207. 
6. Cryptomphalus aspersa mollusc egg extract promotes regenerative effects in human dermal papilla stem cells / M. T. Alameda, E. Morel, C. Parrado // Int. J. Mol. Sci. - 2017. - Vol. 18(2). - P. 463. DOI: 10.3390/ijms18020463.

7. https://www.istitutodielicicoltura.it/it/en/snail-slime

8. Snail mucus - glandular origin and composition in Helix pomatia / S. Greistorfer, W. Klepal, N. Cyran [et al.] // Zoology. - 2017. - Vol. 122. - P. 126-138.

9. Gary B. Gillis. Snail trails / Gary B. Gillis // Journal of Experimental Biology. - 2007. - Vol. 210. DOI: 10.1242/ jeb.001073.

10. Heliv pomatia hemocyanin - a novel bio-adjuvant for viral and bacterial antigens / V. Gesheva, S. Chausheva, N. Stefanova [et al.] // Int. Immunopharmacol. - 2015. Vol. 26, Is. 1. -P. 162-168. DOI: 10.1016/j.intimp.2015.03.011.

11. A secretion of the mollusc Cryptomphalus aspersa promotes proliferation, migration and survival of keratinocytes and dermal fibroblasts in vitro / M. C. Iglesiasde la Cruz, F. Sanz-Rodriguez, A. Zamarron [et al.] // Int. J. Cosmet. Sci. - 2012. - Vol. 34, Is. 2. - P. 183-189. DOI: 10.1111/j.1468-2494.2011.00699.

12. Гричениченко Ю. Д. Использование ахатин в косметологии / Ю. Д. Гричениченко, Є. Л. Маркина. Режим доступу: https://journals.indexcopernicus.com/api/file/ viewByFileld/935488.pd

13. Dosage of bioactive molecules in the nutricosmeceutical helix aspersa muller mucus and formulation of new cosmetic cream with moisturizing effect / S. Laneri, R. D. Lorenzo, A. Sacchi [et al.] // Natural Product Communications. - 2019. - P. 1-7. DOI: $10.1177 / 1934578 \times 19868606$.

14. The effectiveness of snail slime and chitosan in wound healing / A. S. Harti, S. D. Sulisetyawati, A. Murharyati [et al.] // Int. J. Pharm. Med. and Biol. Scienc. - 2016. - Vol. 5, No. 1. - P. 76-80.

15. Thomas S. Medicinal use of terrestrial molluscs (slugs and snails) with particular reference to their role in the treatment of wounds and other skin lesions. Access mode : http://www.worldwidewounds.com/2013/July/Thomas/slugsteve-thomas.html.

16. Molecular basis for the regenerative properties of a secretion of the mollusk Cryptomphalus aspersa / A. Brieva, N. Philips, R. Tejedor [et al.] // Skin. Pharmacol. Physiol. 2008. - Vol. 21, Is. 1. - P. 15-22. DOI: 10.1159/000109084.

17. Особа І. Я. Особливості фрункціонування системи антиоксидантного захисту організму / І. Я. Особа // Рибогосподарська наука України. - 2009. - № 1. - С. 133-139.

\section{REFERENCES}

1. Trapella C, Rizzo R, Gallo S, Alogna A, Bortolotti D, Casciano $F$, et al. HelixComplex snail mucus exhibits pro-survival, proliferaive and pro-migration effects on mammalian fibroblasts. Scientific reports. 2018;8(17665): 1-10. Available from: https://doi.org/10.1038/s41598-01835816-3

2. Bonnemain B. Helix and drugs: snails for health care from Antiquity to these days. Rev Hist Pharm. 2003;51(338): 211-8.

3. Bouchet $P$, Rocroi JP. Classification and nomenclator of gastropod families. Malacologia. 2005;47(1-2): 397.

4. Bonnemain B. Helix and drugs: snails for western
18. Effect of powdered shells of the snail megalobulimus lopesi on secondary-intention wound healing in an animal model / P. H. Muleta Andrade, E. S. Rondon, C. A. Carollo // Evidence-Based Complementary and Alternative Medicine. - 2015. - 9 p. DOI.org/10.1155/2015/120785.

19.https://sciencediscoveries. degruyter.com/snail-slugslime-alternative-conventional-antibiotics.

20. A novel cysteine-rich antimicrobial peptide from the mucus of the snail of Achatina fulica / J. Zhong, W. Wang, X. Yang [et al.] // Peptides. - 2013. - Vol. 39. - P. 1-5. DOI: 10.1016/j.peptides.2012.09.001.

21. Antimicrobial proteins of Snail mucus (Achatina fulica) against Streptococcus mutans and Aggregatibacter actinomycetemcomitans / D. N. Herluinus Mafranenda, Indah Listiana Kriswandini, R. Ester Arijani // Dental Journal. - 2014. - Vol. 47, Is. 1. - P. 31-36.

22. http://news.bbc.co.uk/2/hi/health/900869.stm

23. https://www.Ivrach.ru/2036/partners/15437139

24. Sergysels R. A double-masked, placebo-controlled polysomnographic study of the antitussive effects of helicidine / R. Sergysels, G. Art // Curr. Ther. Res. Clin. Exp. - 2001. - Vol. 62. - P. 35-47.

25. Effect of Helix aspersa extract on TNFa, NF$\mathrm{KB}$ and some tumor suppressor genes in breast cancer cell line Hs578T / El I. Ouar, C. Braicu, D. Naimi [et al.] // Pharmacogn. Mag. - 2017. - Vol. 13, Is. 50. - P. 281-285. DOI: 10.4103/0973-1296.204618.

26. Transforming growth factor- $\beta$ and endoglin signaling orchestrate wound healing / M. Valluru, C. A. Staton, M. W. R. Reed [et al.] // Front. Physiol. - 2011. - Vol. 2. - P. 89. DOI: $10.3389 /$ fphys.2011.00089.

27. Changes in the gene expression profile of the bladder cancer cell lines after treatment with Helix lucorum and Rapana venosa hemocyanin / O. S. Antonova, L. Yossifova, R. Staneva [et al.] // Journal of B.U.ON.: Official Journal of the Balkan Union of Oncology. - 2015. Vol. 20 (1). - P. 180-187.

28. https://www.sciencedaily.com/releases/2019/11/ 191104112830.htm

29. Pharmacokinetic analysis of ziconotide (SNX-111), an intrathecal N-type calcium channel blocking analgesic, delivered by bolus and infusion in the dog / T. L. Yaksh, Annelies de Kater, R. Dean [et al.] // Neuromodulation. - 2012. - Vol. 15, Is. 6. - P. 508-519. DOI: 10.1111/j.1525-1403.2012.00479.x.

30. Kim P. The use of ziconotide in private practice. Access mode : https://www.asra.com/asra-news/article/152/ the-use-of-ziconotide-in-private-practic

health care from antiquity to these present. Evid Based Complement Alternat Med. 2005;2(1): 25-8. Available from: https://doi.org/10.1093/ecam/neh057

5. Jin A-H, Muttenthaler M, Dutertre S, Himaya SWA, Kaas Q, Craik DJ, et al. Conotoxins: Chemistry and Biology. Chem Rev. 2019;119(21): 11510-9. Available from: https:// doi.org/10.1021/acs.chemrev.9b00207

6. Alameda MT, Morel E, Parrado C, Conzales S, Juarranz A. Cryptomphalus aspersa Mollusc Egg Extract Promotes Regenerative Effects in Human Dermal Papilla Stem Cells. Int J Mol Sci. 2017;18(2): 463. Available from: https://doi.org/10.3390/ijms18020463 
7. https://www.istitutodielicicoltura.it/it/en/snail-slime

8. Greistorfer S, Klepal W, Cyran N, Gugumuck A, Rudoll L, Suppan J. et al. Snail mucus - glandular origin and composition in Helix pomatia. Zoology. 2017;122: 126-38. Available from: https://doi.org/10.1016/j.zool.2017.05.001

9. Gillis GB. Snail trails. J Exper Biol. 2007; 210. Available from: https://doi.org/10.1242/jeb.001073

10. Gesheva V, Chausheva S, Stefanova N, Mihaylova $\mathrm{N}$, Doumanova $\mathrm{L}$, Idakieva $\mathrm{K}$, et al. Helix pomatia hemocyanin - a novel bio-adjuvant for viral and bacterial antigens. Int Immunopharmacol. 2015;26(1): 162-8. Available from: https://doi.org/10.1016/j.intimp.2015.03.011

11. Iglesias-de la Cruz MC, Sanz-Rodriguez F, Zamarron A, Reyes E, Carrasco E, Conzález S, et al. A secretion of the mollusc Cryptomphalus aspersa promotes proliferation, migration and survival of keratinocytes and dermal fibroblasts in vitro. Int J Cosmet Sci. 2012;34(2): 183-9. Available from: https://doi.org/10.1111/j.14682494.2011.00699.x

12. Hrychenichenko YD, Markina YL The use of achatina in cosmetology. [Использование ахатин в косметологии] Available from: https://journals.indexcopernicus. com/api/file/viewByFileld/935488.pd. Russian.

13. Laneri S, Lorenzo RD, Sacchi A, Dina I. Dosage of bioactive molecules in the nutricosmeceutical helix aspersa muller mucus and formulation of new cosmetic cream with moisturizing effect. Nat Prod Commun. 2019; 1-7. Available from: https://doi.org/10.1177/1934578X19868606

14. HartiAS, Sulisetyawati SD, MurharyatiA., Oktaiani M. The effectiveness of snail slime and chitosan in wound healing. Int J Pharm Med and Biol Scienc. 2016;5(1): 76-80.

15. Thomas S. Medicinal use of terrestrial molluscs (slugs and snails) with particular reference to their role in the treatment of wounds and other skin lesions. Available from: http://www.worldwidewounds.com/2013/July/Thomas/slugsteve-thomas.html

16. Brieva A, Philips N, Tejedor R, Guerrero A, Pivel JP, Alonso-Lebrero JL, et al. Molecular basis for the regenerative properties of a secretion of the mollusk Cryptomphalus aspersa. Skin Pharmacol Physiol. 2008;21(1): 15-22. Available from: https://doi.org/10.1159/000109084.

17. Osoba IY. [Features of functioning of system of antioxidant protection of an organism]. Nauka rybnoho hospodarstva Ukrainy. 2009;1: 133-9. Ukrainian.

18. Muleta Andrade $\mathrm{PH}$, Rondon ES, Carollo CA, Rodrigues Macedo ML, Viana LH, Schiaveto de Souza A, et al. Effect of powdered shells of the snail megalobulimus lopesi on secondary-intention wound healing in an animal model. J Evid Based Complementary Altern Med. 2015; 9. Available from: https://doi.org/10.1155/2015/120785.

19. https://sciencediscoveries.degruyter.com/snailslug-slime-alternative-conventional-antibiotics

20. Zhong J, Wang W, Yang X, Yan X, Liu R. A novel cysteine-rich antimicrobial peptide from the mucus of the snail of Achatina fulica. Peptides. 2013;39: 1-5. Available from: https://doi.org/10.1016/j.peptides.2012.09.001

21. Herluinus Mafranenda DN, Kriswandini IL, Arijani ER. Antimicrobial proteins of Snail mucus (Achatina fulica) against Streptococcus mutans and Aggregatibacter actinomycetemcomitans. Dental Journal. 2014;47(1): 31-6. Available from: https://doi.org/10.20473/j.djmkg.v47.i1.p3136.

22. http://news.bbc.co.uk/2/hi/health/900869.stm.

23. https://www.lvrach.ru/2036/partners/15437139.

24. Sergysels R, Art G. A double-masked, placebocontrolled polysomnographic study of the antitussive effects of helicidine. Curr Ther Res Clin Exp. 2001;62: 35-47.

25. El Ouar I, Braicu C, Naimi D, Irimie A, BerindanNeagoe I. Effect of Helix aspersa extract on TNFa, NF-KB and some tumor suppressor genes in breast cancer cell line Hs578T. Pharmacogn Mag. 2017;13(50): 281-5. Available from: https://doi.org/10.4103/0973-1296.204618

26. Valluru M, Staton CA, Reed MWR, Brown NJ. Transforming growth factor- $\beta$ and endoglin signaling orchestrate wound healing. Front Physiol. 2011;2: 89. Available from: https://doi.org/10.3389/fphys.2011.00089.

27. Antonova OS, Yossifova L, Staneva R, Stevanovic S, Dolashka P, Toncheva D. Changes in the gene expression profile of the bladder cancer cell lines after treatment with Helix lucorum and Rapana venosa hemocyanin. J BUON. 2015;20(1): 180-7.

28. https://www.sciencedaily.com/releases/2019/11/ 191104112830.htm.

29. Yaksh TL, Annelies de Kater, Dean R, Best BM, Miljanich GP. Pharmacokinetic analysis of ziconotide (SNX-111), an intrathecal N-type calcium channel blocking analgesic, delivered by bolus and infusion in the dog. Neuromodulation. 2012;15(6): 508-19. Available from: https://doi.org/10.1111/j.1525-1403.2012.00479.x

30. Kim P. The use of ziconotide in private practice. Available from: https://www.asra.com/asra-news/ article/152/the-use-of-ziconotide-in-private-practic. 